\title{
The Economic Surplus, Disembedded Economy, and Nurturance Gap-The Contribution of James Ronald Stanfield to Political Economy
}

\author{
Phillip Anthony O'Hara
}

James Ronald Stanfield was born into a poor working class family on November 22, 1945. He was brought up in Handley, Texas, a semi-rural area at the time, went to Eastern Hills High School (in Fort Worth), and at his mother's insistence attended a Methodist church, until the age of thirteen. His parents were of Scotch-Irish and German ancestry and worked as short order café cooks, competing with the emerging take away fast food joints. In his late teens he took to economics as a way of getting out of the culture of poverty, expecting to become an "efficiency expert" or what is now called a management consultant. With this in mind he took a B.A. (1968) with a major in economics and an M.A. in Economics (1969) at the University of Texas at Arlington.

By this time he was drawn into the protests against the Vietnam War and lost his interest in being an efficiency expert, being more concerned with the excesses of the corporate state, the wasteful use of public spending, and the need for more reasonable foreign and domestic policies. Ron, as his friends and colleagues call him, was then drawn back to economics from a brief stint in English by the promise that the study of economic imperialism would reveal the hidden reality behind U.S. foreign policy. That promise was problematic, but Ron was attracted by the new groupings of institutionalists and neo-Marxists who started to organize conferences and journals in the USA in the mid to late 1960s. Following this radicalization he did an empirical $\mathrm{Ph} . \mathrm{D}$. thesis on the economic surplus at the University of Oklamoma-Norman (1972).

Phillip O'Hara is Professor of Global Political Economy and Governance in the Global Political Economy Research Unit, Economics Department, Curtin University, Perth, Australia. This paper was presented at the Association for Evolutionary Economics annual meetings, Boston, January 6-8,2006. The author wishes to thank Ron Stanfield for decades of stimulating analysis and friendship. Email: philohara@runbox.com. 
His world of ideas was stimulated by greats such as Thorstein Veblen, Karl Polanyi, Erich Fromm, John Kenneth Galbraith, Paul Baran, Paul Sweezy, Herbert Marcuse, Clarence Ayres, Robert Theobald, and Thomas Kuhn. Veblen and Galbraith wrote with insight and honor about the sociocultural ramifications of the new industrial state; Baran and Sweezy on the cultural contradictions of monopoly capital; and Fromm and Marcuse on surplus repression and misdirected Freudian sublimation of the atrophied social relations of production. Ayres, Polanyi, and Theobald emphasized the need to imagine more desirable alternative futures, while Kuhn called attention to revolutions and paradigms in science. These fresh ideas gave young Ron an apprenticeship for understanding institutional adjustment through cultural change.

\section{Stanfield's Contributions to Institution Building}

Ron Stanfield has since contributed much to an understanding of institutional change through cultural change. It is not surprising, therefore, to find that he played a leading role in the institutions themselves. He had in the late 1960 s joined the Union for Radical Political Economics (URPE) and Democratic Socialists of America (DSA), while publishing in the Review of Radical Political Economics in the mid 1970s, to illustrate his commitment to radical change. Then he became an active member of the Association for Evolutionary Economics (AFEE) and for more than three decades has been advancing the cause of institutional economics. For instance, he has published twenty-one articles in AFEE's Journal of Economic Issues (JEI) on subjects ranging from Kuhnian revolutions to linkages between institutionalism and Marxism, the current crises of capitalism, the institutional economics of Polanyi, Galbraith, and Ayres, monopoly capital, the role of the state, and the nature of nurturance and love. He also served on the editorial board of the JEI (1978-1981) as well as being a member of the board of directors of AFEE (1981). In 1998 he became the president of AFEE and delivered a paper on "The Scope, Method, and Significance of Original Institutional Economics" (1999) in that capacity. In January 2006 in Boston he received the greatest accolade possible in political economy, the Veblen-Commons Award, for his outstanding contributions to institutional economics.

In the late 1970s, the Association for Institutionalist Thought (AFIT) was formed with a view to going back to the roots of institutional economics through the work of Veblen, Wesley Mitchell, John Commons, and Ayres. At the time, AFEE was taking a rather eclectic role in analyzing different varieties of institutional economics and the linkages among institutionalists and Marxists, neoclassicists and public choice theorists. The idea was that AFIT should redirect the activities of institutionalists to the core of its thought. AFIT even developed an alternative journal, the Review of Institutional Thought, edited by Dale Bush through 1980-1983. Out of concern that sectarian activities may weaken the somewhat precarious footing of AFEE and original institutional economics, Ron played no role in the early years of AFIT. But when its complementary relation to 
AFEE evolved he joined AFIT and took an active role in its activities, subsequently serving on its board and becoming its president in 1995.

Ron also played a critical part in the Association for Social Economics (ASE), an organization that in an earlier life had been a vehicle of Catholic economists and since the 1960s had become more heterodox and inclusive for economists concerned with the role of society, values, and ethics. Early on he received the Helen Potter Award for the best article published in ASE's Review of Social Economy (RoSE) for 1975, "On the Crisis of Liberalism," where he outlined the problems for liberal democracy in the light of the contemporary crises of capitalism. During 1980-82 he was an elected member of the executive council, being engaged in the administration of ASE. He became a guest editor for a 1992 issue of RoSE on "Economy and Society at the Close of the American Century," a member of the editorial board for the past sixteen years, and president of ASE during 1993. In 2002 he was presented with the Thomas Divine Award for Lifetime Contributions to social economics.

He also promoted institution building at Colorado State University, where he started as assistant professor of economics in 1974, became associate professor in 1976, and then full professor in 1981. At Fort Collins he was coordinator of graduate studies during 1982-1990 and 2000-2003; taught regular units in institutional economics, Marxian economics, comparative political economy, and the history of economic thought; and received both the Pennock Distinguished Service Award for 1988-89 and the John H. Stern Distinguished Professor Award in 1999. He was energetic in building a strong undergraduate and $\mathrm{Ph} . \mathrm{D}$. program in political economy with fellow colleagues such as Rodney Peterson, Bob Keller, Bud Hartman, David Seckler, Bob Kling, Alexandra Bernasek, Ronnie Phillips, Terry Ozawa, and Steven Shulman.

For over thirty years Stanfield has been sharing his wisdom of cultural advance through institutional adjustment with several generations of students at Colorado State. For instance, he was the principal supervisor for seventeen $\mathrm{Ph}$.D. students, including dissertations on such diverse topics as Marxian, heterodox, Catholic, Austrian, and Budapest schools; the political economy of Robert Heilbroner, Commons, and Rexford G. Tugwell; plus the role of culture, welfare, housing, labor, information, transitional economies, and media. He was a supervisor for well-known institutionalists such as Raymond Benton, Douglas Brown, Michael Carroll, Douglas Kinnear, Aric Krause, and Brent McClintock, plus numerous rising stars such as Pamela Jackson, Kurt Keiser, Thomas Kemp, Robert LaJeunesse, Laura Taylor, Mary Wrenn, and Tim Wunder. Other students who took Ron's classes have played important roles in sustaining social and institutional economics, including Jim Swaney, Ann Mari May, Bruce McDaniel, Marie Lingstone, Chuck Sperry, Larry Sanders, Terrel Gallaway, Julie Gallaway, and Karen Sable. 


\section{The Economic Surplus and Social Reproduction}

Stanfield was one of the first to analyze the dynamics underlying the production and distribution of the "economic surplus" in the wake of Paul Baran and Paul Sweezy's (1966) scrutiny of Monopoly Capital. This he did in his Ph.D. thesis at the University of Oklamoma, Norman, under the supervision of Nelson Peach (with Tom Curtis directing his thesis committee). Almost immediately a version of the thesis was printed by a commercial publisher, Lexington Books in Massachusetts, as The Economic Surplus and Neo-Marxism (1973). At a time when radical political economy was in its heyday, books and articles on the operational dynamics of contemporary capitalism were much in demand. Baran and Sweezy were the parents of this intellectual movement, and Stanfield was one of the most conspicuous offspring to emerge.

Being dedicated to "Paul Sweezy and the memory of Paul Baran," the book studied the concept of the economic surplus, the nature of essential personal and social consumption, and an estimation of essential consumption, potential output, and the economic surplus. Three of Baran and Sweezy's main hypotheses are critically examined, and two of them found to be problematic. The main hypothesis of a strong and systematic tendency for economic surplus to rise, "both absolutely and as a share of total output," was found to be consistent with the evidence for the USA during 1932-1970. Both potential and actual surplus tended to rise, with some slight falls during a few years which did not negate the main tendency (Stanfield 1973, 81). Thus, changes in institutions, knowledge, technique, skill, and effort enabled the economic surplus to advance through time during most of the twentieth century.

The two hypotheses found to be questionable were especially important to a critical analysis of modern capitalism. The first of these is the idea that the investment portion of the surplus tends to rise, and the second is that the normal state of monopoly capitalism is necessarily one of stagnation. Stanfield found that the investment portion did not tend to rise because of the importance of resources for reproducing the social classes and the institutions of society. He similarly found that there is no inherent tendency in capitalism for stagnation because the institutions are sometimes able to be reconstructed to deal with anomalous trends (1974).

These two revisions of Baran and Sweezy's work on monopoly capitalism are ones that many political economists have, even now, failed to emphasize, since they reflect fundamental innovations that are often difficult to propagate. As Bush (2001) recognized, institutional innovations are often inhibited by the entrenched vested interests and values. The first innovation contributed by Stanfield was the concept of socioeconomic reproduction. Of all the political economists of the last hundred years, no one has made more contributions to this than Stanfield. It is understandable, then, that "reproduction" became the central theme of his second book, Economic Thought and Social Change, published by Southern Illinois University Press in 1979.

This concern of Stanfield for the psycho-cultural consequences of an insufficiently progressive reproduction of the social economy led him to examine crisis tendencies of 
capitalism. He saw a close link between the inability of capital to suitably reproduce the social-cultural integrity of the system and the emergence of economic crises and financial instability. The second innovation of Stanfield was to develop further the concept of system contradiction where there are cultural inconsistencies between the interests of individual persons and companies and the viability of the system as a whole. System contradictions imply that resources and energy need to be directed to the coherence of institutions in the larger cultural environment. A lack of coherence leads to conflict, instability, and problematic socioeconomic performance. Stanfield's work thus involves analyzing the national and international structural crises that emerged in the 1970 s-2000s. He therefore came to support the concept of long waves in the political economy of institutions, broadly in line with the work of radical political economists (O'Connor 1984; Gordon, Weisskopf, and Bowles 1994). This led to a broader recognition by Stanfield of a close connection between institutional, neo-Marxian, and radical political economy in a series of articles and culminating in a book ( $\mathrm{I}$ think his best one), Economics, Power, and Culture: Essays in the Development of Radical Institutionalism (1995), ${ }^{1}$ as well as his proposal for the use of the economic surplus as a fund for social change (1992).

\section{Karl Polanyi and the Disembedded Economy}

Stanfield's analysis of the economic surplus and the fund for social change provides a conceptual apparatus for understanding the anomalous workings of advanced capitalism. The socioeconomic reproduction of capitalism requires investing resources into institutions to rectify the problem of psycho-cultural malaise characteristic of market society. Polanyi's $(1944,1968)$ idea of the disembedded economy explains why the dominance of the market creates system problems. These ideas are detailed in Stanfield's third book, The Economic Thought of Karl Polanyi (1986) plus a host of his academic articles (e.g., Stanfield 1980, 1982).

As a result (mainly) of Stanfield's work, the Polanyian concept of the disembedded economy is basic to institutional economics. ${ }^{2}$ Polanyi himself was born in Vienna in 1886 , being a professor at Columbia in the 1940 s and 1950s. His analysis of early cultures taught him both the importance of a "substantive" economics of the way of life of the community and the need for nonmarket institutions in economic life. In precapitalist societies, for instance, purely economic institutions were found to be either nonexistent or secondary to social and political relationships. This enabled them to slowly evolve through thousands of years of reproduction devoid usually of major system problems.

The problem with market capitalism, according to Polanyi, is that economic relationships of money and commodities dominate political and social institutions, leading to structural and periodic instability. The system is thus continually engaged in varying degrees of uncertainty as the process of change and metamorphosis questions estab- 
lished ways of life. This puts pressure on human beings and nature, leading to cultural and environmental degradation. These "externalities," Stanfield realized, thus become endogenous results of a system that is forever undergoing transformation and destructive creation. Capitalism thus has a principal contradiction that it forever establishes new practices, technologies, and skills which require people and nature to perpetually move habitat, upset family linkages, and re-establish new habits and relationships. The instabilities of the system adversely impact system reproduction and thereby create periodic structural crises.

Stanfield was the first to systematically analyze the significance of Polanyi's work for institutional economics and economic policy, as well as to situate the disembedded economy in the field of modern political economy. The disembedded tendency revealed to him why certain institutions are required for sustained profit and accumulation, as well as potentially for a new stable social system devoid of massive dislocation. Embedding-style institutions are needed in economic life to give meaning to people's lives and also to enable livelihood to be sustainable in the long term. Such institutions are, therefore, the very substance of reality that enables people's habits to link with the prevailing norms and mores, thereby enabling social life to be reproduced. Economics thus needs to be a substantive science of real processes and relationships, where the economy is embedded in culture, rather than dominating people's lives so as to dislocate their whole being (see also Stanfield 1996). Of course, some social institutions are more instrumental to human society than others and therefore need to be critically scrutinized according to the degree to which they are ceremonially dominant. ${ }^{3}$

\section{Great Capitalist Restoration, Nurturance, and Love}

What, then, are the implications of Stanfield's political economy of institutions and culture for the contemporary workings of capitalism and its system of governance? This is explored through an analysis of the dominant institutions at work in the social economy. These dominant spheres include family and community, ecology and nature, state and government, corporation and production chains, plus markets and money. The great (potentially) embedding institutions are those of family and community plus ecology and nature.

Family and community include the dominant transactions of reciprocity and redistribution, where nurturance and love have historically generated relationships between people based on sharing and domestic chores. The past two decades, however, have reproduced contradictory tendencies in this sphere. On one hand, the positive tendencies create difference and flexibility, where families have become more variable and multifarious in nature and where members have less control and more fluidity of movement and role. But like every contradiction, the negatives are ever-present and recently have become fairly dominant. Reciprocity and redistribution have declined in the typical Western family as members have become more concerned with the self, and relation- 
ships have typically become more unstable and less durable. The sharing tendency has been replaced by the self-serving trend, leading to less trust and sociality within families and communities (Stanfield and Stanfield 1997).

The historically embedding institutions of ecology and nature have also become transformed. Traditionally, the natural environment has provided human communities with access to resources such as oxygen, space, material resources, food, beauty, and companionship from other species. But as ecological capital has made way for business and human capital the natural habitats have been destroyed to often high levels. Species extinction is accelerating as biodiversity diminishes; global warming is accelerating as pollutants reduce the degree of sustainability of economic processes; and species stress increases as human population density increases.

The institutions of the market, therefore, were reinforced during the $1980 \mathrm{~s}-2000 \mathrm{~s}$, while reciprocity and redistribution were inhibited. The domestic financial market, foreign capital market, and labor market were all deregulated during the 1970s-1990s. People were encouraged to promote their own individual interests, be all they can be, and reinvigorate the American dream. Fewer people now join unions, political groups, community organizations and such things as bowling clubs. People put resources into work and study plus groups promoting financial security, personal fitness, and psychological health. As a result, nurturance and love decline in favor of self and the "me generation." Market transactions increase at the expense of reciprocity and redistribution. The disembedded economy deepens while financial and corporate crises gain in amplitude (Stanfield and Stanfield 1997.)

The Polanyian double movement-of deregulation followed by reaction to crises-is being seen daily in national and global economies. As a result, there is emerging a backlash against neoliberalism in the form of the post-Washington consensus, progressive governments in Latin America, and the post-autistic movement in political economy. The policy implications of these changes are that financial and corporate institutions need to have greater stability to prevent the rise and fall of massive speculative bubbles and corporate crises. Asset-backed reserve requirements and changing accounting cultures are required to reduce fraud and conflicts of interest. More productive government spending is needed to promote social capabilities in the areas of education, health, infrastructure, and communication, while public utilities should enhance essential consumption. Social institutions require reorganization, including the work environment to promote participatory democracy and work-family relations to stimulate trust and sociality. International relations seriously depend on successful multilateral agreements and effective global institutions to protect the rule of law, sovereign governments, the environment, and threats to security (O'Hara 2006). The new vision is holistic, integrative, participatory, and aware of the potential problems of situating the individual outside the social fabric. Governance needs to balance agency and structure, with a long-term vision and recognition of the problems besetting cleavages based on class, ethnicity, gender, nation and species. 


\section{Conclusion}

Stanfield has for thirty-five years and continues to be an energetic contributor to political economy. He has made inroads into institution building at Colorado State University as well as within professional organizations such as the Association for Evolutionary economics, the Association for Social Economics, and the Association for Institutional Thought. He is a leader of the radical institutionalist movement that comprehends the nature and problems of neoliberal capitalism in terms of psycho-cultural and environmental degradation. He is promoting trust and sociality among scholars to improve their well-being and contribute to a shared yet critical understanding of contemporary capitalism. He is contributing to the policy debate vis-à-vis the double movement and the importance of public goods and social institutions solving socioeconomic problems. He is a good friend and colleague to many people.

Stanfield teaches us to treat the economy as a social system with humanity and the environment at its core. Economics should not be a mere play thing for promotion and individual enhancement. It is necessary to understand and promote both individuality and sociality concurrently. This can be done through a paradigm that treats structure and agency as interdependent and a progressive agenda that deepens participatory social processes and community linkages. Nurturance, friendship, love, and ecological sustainability need to be advanced while promoting livelihood for the majority of the population. The cleavages of class, ethnicity, gender, nation, and species can be moderated through a progressive agenda of reform. This is the basic message to be learned from the continuing work of Ron Stanfield. We can do well to take him as a point of departure for how best to understand political economy and promote social change.

\section{Notes}

1. From these roots emerged the trend of "radical institutionalism" through the work of Rick Tilman, Ron Stanfield, Bill Dugger, and a host of other scholars. Radical institutionalism thus emerged as a critical movement in modern political economy, recognizing especially the symbiotic linkages between Marxism and institutionalism. As Stanfield $(1977,68)$ says, they "can learn from [each] other and perhaps be strengthened by synthesis." On this trend, see also the work of Douglas Brown (1998), Dugger (1989), Dugger and William Waller (1992), Janice Peterson and Brown (1994), Phillip O'Hara (2000), Stanfield (1977, 1978, 1989), and Tilman (1996).

2. Of course, others have also contributed to a Polanyian analysis of the disembedded economy in the Journal of Economic Issues. See, for instance, the work of Walter Neale (1991), William Schaniel and Neale (2000), and Antonio Sanchez-Andres and Jose M. March-Poquet (2002).

3. This reference to instrumental and ceremonial functions of institutions, of course, alludes to the work of Dale Bush and his close colleague Marc Tool, who work in what may be referred to as the instrumentalist school of institutionalism. It follows closely from the work of Veblen, John Dewey, Fagg Foster, and others. According to this tendency in institutionalism, instrumental and ceremonial functions of institutions are embedded in all relationships, and the critical thing is the degree to which they are ceremonially encapsulated in the institutions. There is a close linkage between radical institutionalism and instrumental institutionalism, 
the latter of which may be considered as a radical-liberal wing of the movement. See the work of Bush (2001), Tool (2001), and Tool and Bush (2002) for detail on these ideas.

\section{References}

Baran, Paul A., and Paul M. Sweezy. Monopoly Capital: An Essay on the American Economic and Social Order. New York: Monthly Review Press, 1966.

Brown, Douglas M., ed. Thorstein Veblen in the Twenty-First Century: A Commemoration of "The Theory of the Leisure Class" (1899-1999). Cheitenham, U.K., and Northampton, Mass.: Edward Elgar, 1998.

Bush, Paul Dale. "Institutional Change and Adjustment." In Encyclopedia of Political Economy, edited by Phillip Anthony O'Hara, 698-702. London and New York: Routledge, paper edition, 2001.

Dugger, William M., ed. Radical Institutionalism: Contemporary Voices. New York and London: Greenwood Press, 1989.

Dugger, William M., and William Waller, eds. The Stratified State: Radical Institutionalist Theories of Participation and Duality. London and Armonk, N.Y.: M. E. Sharpe, 1992.

Gordon, David, Thomas E. Weisskopf, and Samuel Bowles. "Power, Accumulation, and Crisis: The Rise and Demise of the Postwar Social Structure of Accumulation." In Radical Political Economy: Explorations in Al. ternative Economic Analysis, edited by Victor D. Lippit, 226-246. Armonk, N.Y., and London: M. E. Sharpe, 1994.

Neale, Walter C. "Society, State, and Market: A Polanyian View of Current Change and Turmoil in Eastern Europe." Joumal of Economic Issues 25 (June 1991): 467-73.

O'Connor, James. Accumulation Crisis. Oxford: Blackwell Publishers, 1984.

O'Hara, Phillip Anthony. Marx, Veblen, and Contemporary Institutional Political Economy: Principles and Unstable Dynamics of Capitalism. Cheltenham, U.K., and Brookfield, Vt.: Edward Elgar, 2000.

- Growth and Development in the Global Political Economy: Social Structures of Accumulation and Modes of Regulation. London and New York: Routledge/Taylor and Francis, 2006.

Peterson, Janice, and Doug Brown, ed. The Economic Status of Women Under Capitalism: Institutional Economics and Feminist Theory. Aldershot, U.K., and Brookfield, Vt.: Edward Elgar, 1994.

Polanyi, Karl. The Great Transformation. 1944. Reprint, Boston: Beacon Press, 1957.

—. Primitive, Archaic, and Modern Economies: Essays of Karl Polanyi. Edited by George Dalton. Boston: Beacon Press, 1968.

Sanchez-Andres, Antonio, and March-Poquet, Jose M. "The Construction of Market Institutions in Russia: A View from the Institutionalism of Polanyi." Journal of Economic Issues 36 (September 2002): 707-722.

Schaniel, William C., and Walter C. Neale. "Karl Polanyi's Forms of Integration as Ways of Mapping." Journal of Economic Issues 34 (March 2000): 89-104.

Stanfield, James Ronald. The Economic Surplus and Neo-Marxism. Lexington, Mass., and London: Lexington Books, 1973.

—. "A Revision of the Economic Surplus Concept." Review of Radical Political Economics 6 (Fall 1974): 69-77. Reprinted in The Faltering Economy: The Problem of Accumulation under Monopoly Capitalism, edited by John Bellamy Foster and Henryk Szlaijfer, 251-261. New York: Monthly Review Press.

"On the Crisis of Liberalism." Review of Social Economy 33 (Spring 1975): 153-165.

—. "Limited Capitalism, Institutionalism, and Marxism." Journal of Economic Issues 11 (March 1977):61-71.

- Economic Thought and Social Change. Carbondale and Edwardsville, U.S.; London; and Amsterdam: Southern Illinois University Press and Feffer and Simons Inc, 1979.

—. "The Institutional Economics of Karl Polanyi." Joumal of Economic Issues 14 (September 1980): 593-614.

—. "Learning from Primitive Economies." Journal of Economic Issues 16 (June 1982): 471-9.

The Economic Thought of Karl Polanyi: Lives and Livelihood. New York: St Martins Press, 1986.

—. "Veblenian and Neo-Marxian Perspectives on the Cultural Crisis of Late Capitalism." Joumal of Economic Issues 23 (September 1989): 717-734.

"The Fund for Social Change." In The Economic Surplus in Advanced Economies, edited by John B. Davis, 130-148. Aldershot, U.K.: Edward Elgar, 1992. 
- Economics, Power, and Culture: Essays in the Development of Radical Institutionalism. New York and London: St. Martin's Press and Macmillan, 1995.

John Kenneth Galbraith. New York: St Martins Press, 1996.

- "The Scope, Method, and Significance of Original Institutional Economics." Journal of Economic Issues 33 (June 1999): 231-55.

Stanfield, James Ronald, and Jaqueline Bloom Stanfield. "Where Has Love Gone? Reciprocity, Redistribution, and the Nurturance Gap." Journal of Socio-Economics 26, no. 2 (1997): 111-127.

Tilman, Rick. The Intellectual Legacy of Thorstein Veblen: Unresolved Issues. London and Westport, Conn.: Greenwood Press, 1996.

Tool, Marc. The Discretionary Economy: A Normative Theory of Political Economy. 3d ed. Philadelphia: Transaction Press, 2001.

Tool, Marc, and Paul Dale Bush. Institutional Analysis and Policy. Boston: Kluwer Academic Publishers, 2002. 